\title{
Designing of Solar Air Conditioning for Four Wheeler
}

\author{
Basavraja K. T11, M. Rajesh², M. Krishnaven², P. Sachin' ${ }^{2}$ \\ ${ }^{1}$ Assistant Professor, ${ }^{2}$ Student \\ Department of Mechanical Engineering, Guru Nanak Institute of Technology, Rangareddy, Telangana, India
}

\begin{abstract}
How to cite this paper: Basavraja K. T | M. Rajes | M. Krishnaven | P. Sachin "Designing of Solar Air Conditioning for Four Wheeler" Published in International Journal of Trend in Scientific Research and Development (ijtsrd), ISSN: 24566470, Volume-3 | Issue-3, April 2019, pp.1216-1219, URL: https://www.ijtsrd.c om/papers/ijtsrd23 281.pdf

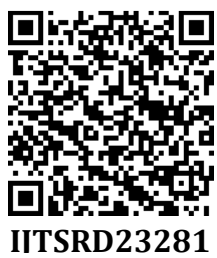

Copyright (c) 2019 by author(s) and International Journal of Trend in Scientific Research and Development Journal. This is an Open Access article distributed under the terms of the Creative Commons

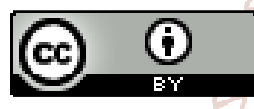
Attribution License (CC BY 4.0) (http://creativecommons.org/licenses/ by $/ 4.0$ )

\section{INTRODUCTION}

As a kind renewable energy solar energy is paid more and more in the world. Solar system can be classified into two categories; those are thermal systems which convert solar energy to thermal energy and photovoltaic systems which convert solar energy to electrical energy. However more solar radiation which falling on photovoltaic cells is not converted to electricity, but either reflected or converted to thermal energy. This method leads to a drop of electricity conversion efficiency due to an increase in photovoltaic cells working temperature[1]. In the past century, scientific community has devoted much effort to procure energy sustainability of housing in two main direction; those are reducing external energy supply and using renewable energy for the remaining. In both ways, solar resources are gaining popularity because they increase energy independence and sustainability at the same time offering nearly zero impact to the environment [1]. The earth's surface receives a daily solar dose of $10 \mathrm{E}+8 \mathrm{KW}$-hr, which is equivalent to 500,000 billion oil barrels that is one thousand times any oil reserve known to man. And the solar energy is collector area dependent, and is a diluted form of energy and is available for only a fraction of the day[6]. A lot of research is being conducted where there is high availability of solar energy just like in India. Solar energy is abundant in summer months where there is no heating load, but instead of cooling is required. But the today's energy sources as shown in Fig. (1.1)

\section{ABSTRACT}

In present day scenario natural resources like fuel, coal are used extremely and drastically. So it's high time for the people all over the world to find the batteries is one example to say that technology is progressing at a brisk phase.

To use solar energy and convert it further into electrical energy requires some collected solar energy and a single phase DC motor which is run by battery By the functioning of these components, making a note of dimension of the vehicle, material used for preparing vehicle (outer body and glass) heat load sources of energy in coming the days due to its abundant availability. 
the same which is at around $14 \%$ while the nuclear power will drop from $7 \%$ to $5 \%[3]$. Hence, the negative effects of fossil fuel combustion on the environment with limited stock can force many countries seeking environmentally friendly alternatives to sustain the increasing energy demand. In this condition, the improvement in the quality of life is raising with the indigenous energy resources. The growth of scarcity in fossil fuels has raised the global interest in the harnessing of solar energy[3]. Solar power is a renewable energy while currently covering and assisting in merely a small portion of global energy demands. However, Photovoltaic (PV) power generates less than $1 \%$ of total electricity supplies since solar power has been considered as one of the most expensive sources of renewable energies [3].

\section{Design and calculations}

Calculations can be done for and designed vehicle in CATIA

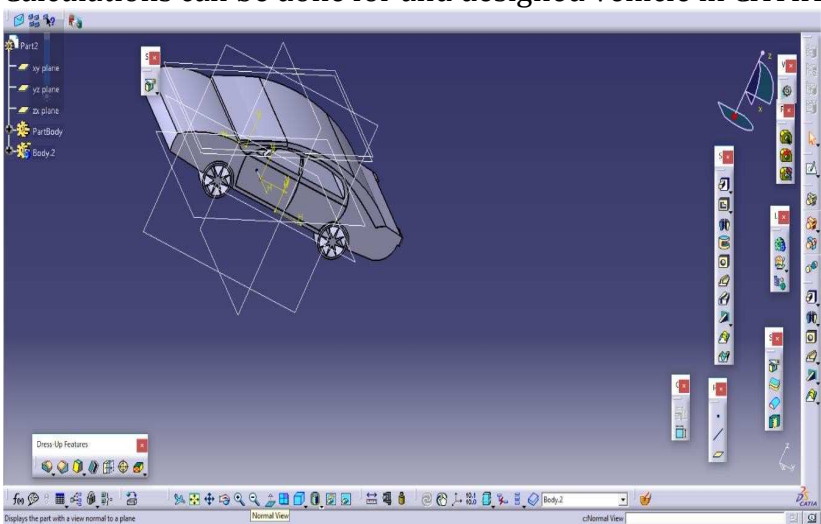

Fig 1 Car model

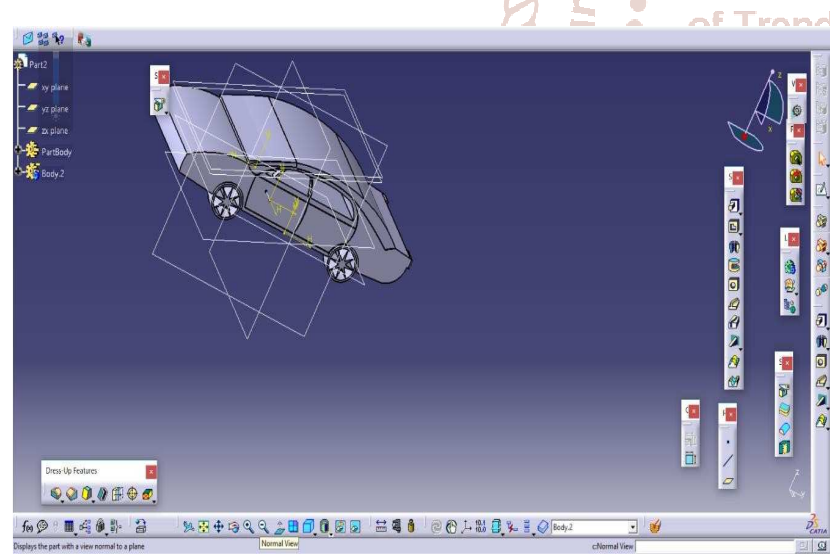

Fig 2 wire frame model

\section{Calculations}

\section{Metabolic Load}

The metabolic activities inside human body constantly create heat and humidity (i.e. perspiration). This heat passes through the body tissues and is finally released to the cabin air. This metabolic load can be calculated by

$\mathrm{Q}_{\mathrm{Met}}=\sum \mathrm{MA}_{\mathrm{Du}}$

Where $\mathrm{M}=$ Passenger metabolic heat production rate $=85 \mathrm{~W} / \mathrm{m}^{2}$ for driver $=55 \mathrm{~W} / \mathrm{m}^{2}$ for passenger

$\mathrm{M}=85+55^{*} 4$ (No. of passengers)

$=305 \mathrm{~W} / \mathrm{m}^{2}$

$\mathrm{A}_{\mathrm{Du}}=$ Body surface area
$A_{\text {Du }}=0.202 \mathrm{~W}^{0.425} \mathrm{H}^{0.725}$ where $\mathrm{W}$ and $\mathrm{H}$ are the passenger weight and height

$=0.202 * 65^{0.425 * 1.70 .725}$

$=1.749504 \mathrm{~m}^{2}$

$\mathrm{Q}_{\text {Met }}=305^{*} 1.749504$

$=533.5988112 \mathrm{~W}$

\section{Radiation Load}

The heat gain due to solar radiation is a significant part of the cooling loads encountered in vehicles. According to ASHRAE, solar radiation heat load can be categorized into direct, diffuse, and reflected radiation loads.

Direct radiation is that part of the incident solar radiation which directly strikes a surface of the vehicle body, which is calculated from

$\mathrm{Q}_{\text {Dir }}=\sum \mathrm{S} \tau \mathrm{i}_{\text {Dir }} \cos \theta$

According to ASHRAE 2007 chapter 33 Table no. 20

Peak load $=1417 \mathrm{~W} / \mathrm{m}^{2}$

$\mathrm{i}_{\text {Dir }}=1417 \mathrm{~W} / \mathrm{m}^{2}$

Glass surface area $\mathrm{S}=2 \mathrm{~m}^{2}$

$\tau=0.5$

$\theta=60^{\circ}$

$\mathrm{Q}_{\text {Dir }}=2^{*} 0.5^{*} 1417^{*} \cos \left(60^{\circ}\right)$

$=708.5 \mathrm{~W}$

On cloudy days, most of the solar radiation is received from this diffuse radiation. This can be calculated by

$\mathrm{Q}_{\text {Dif }}=\sum \mathrm{S} \tau \mathrm{i}_{\text {Dif }}$

$\mathrm{i}_{\text {Dif }}=\mathrm{Ci}_{\text {Dir }}\left(1+\cos \sum\right) / 2$

$=0.103 * 1417 *\left(1+\cos 30^{\circ}\right) / 2$

$=136.174 \mathrm{~W} / \mathrm{m}^{2}$

$\mathrm{Q}_{\text {Dif }}=2 * 0.5 * 136.174$

$=136.174 \mathrm{~W}$

Reflected radiation refers to the part of radiation heat gain that is reflected from the ground and strikes the body surfaces of the vehicle. The reflected radiation is calculated by

$$
\begin{aligned}
& \mathrm{Q}_{\text {Ref }}=\sum \mathrm{S} \tau \mathrm{i}_{\text {Ref }} \\
& \mathrm{i}_{\text {Ref }}=\left(\mathrm{i}_{\text {Dir }}+\mathrm{i}_{\text {Dif }}\right)^{*} \rho \mathrm{g}^{*}\left(1-\cos \sum\right) / 2 \\
& =(1417+136.174)^{*} 0.2^{*}\left(1-\cos 30^{0}\right) / 2 \\
& =20.808 \mathrm{~W} / \mathrm{m}^{2} \\
& \mathrm{Q}_{\text {Ref }}=2^{*} 0.5^{*} 20.808 \\
& =20.808 \mathrm{~W}
\end{aligned}
$$

Thenetabsorbed heat of each surface element dueto radiation can thus be written as

$\mathrm{Q}_{\mathrm{S} . \mathrm{Rad}}=\mathrm{S} \alpha\left(\mathrm{i}_{\text {Dir }} \cos \theta+\mathrm{i}_{\text {Dif }}+\mathrm{i}_{\text {Ref }}\right)$

$=2 * 0.3\left(1417^{*} \cos 60^{0}+136.174+20.808\right)$ for glass

$=519.6208 \mathrm{~W}$

$\mathrm{Q}_{\text {S.Rad }}=3.02 * 0.4\left(1417 * \cos 60^{\circ}+136.174+20.808\right)$ for surface $=1045.5022 \mathrm{~W}$

$Q_{\text {S.Rad }}=519.6208+1045.505$

$=1565.12 \mathrm{~W}$

\section{Ambient Load}

The ambient load is the contribution of the thermal load transferred to the cabin air due to temperature difference between the ambient and cabin air. 
$\mathrm{Q}_{\mathrm{Amb}}=\sum \mathrm{SU}\left(\mathrm{T}_{\mathrm{s}}-\mathrm{T}_{\mathrm{i}}\right)$

For glass $S=2 \mathrm{~m}^{2}$

Speed $=60 \mathrm{kmph}$

$\mathrm{V}=60 * 5 / 18=16.66 \mathrm{~m} / \mathrm{s}$

Where $U$ is the overall heat transfer coefficient of the surface element

$\mathrm{U}=1 / \mathrm{R}$

Where $\mathrm{R}=1 / \mathrm{h}_{0}+\chi / \mathrm{k}+1 / \mathrm{h}_{\mathrm{i}}$

$\mathrm{R}$ is the net thermal resistance for a unit surface area. ho and hi are the outside and inside convection coefficients, $\mathrm{k}$ is the surface thermal conductivity, and $\lambda$ is the thickness of the surface element.

$\mathrm{h}=0.6+6.64(\mathrm{~V})^{0.5}$

Where $\mathrm{h}$ is the convection heat transfer coefficient in $\mathrm{W} / \mathrm{m}^{2} \mathrm{~K}$ and $\mathrm{V}$ is the vehicle speed in $\mathrm{m} / \mathrm{s}$.

$$
\begin{aligned}
\mathrm{h}_{\mathrm{i}} & =0.6 \\
\mathrm{~h}_{0} & =0.6+6.64(16.66)^{0.5} \\
& =27.70
\end{aligned}
$$

For glass $\mathrm{k}=1.05, \chi=0.003 \mathrm{~m}$

$$
\begin{array}{ll}
\mathrm{R} & =1 / 27.70+0.003 / 1.05+1 / 0.6 \\
\mathrm{R} & =1.705 \mathrm{~m} / \mathrm{W} / \mathrm{m} . \mathrm{K} \\
\mathrm{U} & =1 / 1.705=0.586 \mathrm{~W} / \mathrm{m}^{2} . \mathrm{K} \\
\mathrm{Q}_{\text {Amb }} & =2^{*} 0.586^{*}(60-30) \\
& =35.16 \mathrm{~W}
\end{array}
$$

For surface $\mathrm{k}=0.2, \chi=10, \mathrm{~S}=3.02 \mathrm{~m}^{2}$

$\mathrm{R} \quad=1 / 27.70+0.01 / 0.2+1 / 0.6$

$=1.753 \mathrm{~m} / \mathrm{W} / \mathrm{m} \cdot \mathrm{K}$

$\mathrm{U} \quad=1 / 1.753=0.570 \mathrm{~W} / \mathrm{m}^{2} . \mathrm{K}$

$\mathrm{Q}_{\text {Amb }}=3.02 * 0.570 *(60-30)$

$=52.155 \mathrm{~W}$

$\mathrm{Q}_{\mathrm{Amb}}=$ Glass + Surface

$=35.16+52.155$

$=87.315 \mathrm{~W}$

\section{Exhaust Load}

Conventional and hybrid electric vehicles have an Internal Combustion Engine (ICE) that creates exhaust gases. The Exhaust Gas Temperature (EGT) can reach as high as $1000^{\circ} \mathrm{C}$.

Because of the high temperature of the exhaust gas, some of its heat can be transferred to the cabin through the cabin floor. Considering SExh as the area of the bottom surface in contact with the exhaust pipe, the exhaust heat load entering the cabin can be written as

The exhaust heat load entering the cabin can be written as

$$
\begin{aligned}
\mathrm{Q}_{\text {Exh }} & =\mathrm{S}_{\text {Exh }} \mathrm{U}\left(\mathrm{T}_{\text {Exh }}-\mathrm{T}_{\mathrm{i}}\right) \\
\mathrm{T}_{\text {Exh }} & =0.138 R P M-17 \\
& =0.138^{*} 6000-17 \\
& =811 \mathrm{~K} \\
\mathrm{Q}_{\text {Exh }} & =0.035^{*} 0.570 *(811-30) \\
& =15.88 \mathrm{~W}
\end{aligned}
$$

\section{Engine Load}

Like the exhaust load above, the high temperature engine of a conventional or hybrid car can also contribute to the thermal gain of the cabin

$$
\begin{aligned}
\mathrm{Q}_{\text {Eng }} & =\mathrm{S}_{\text {Eng }} \mathrm{U}\left(\mathrm{T}_{\text {Eng }}-\mathrm{T}_{\mathrm{i}}\right) \\
\mathrm{T}_{\text {Eng }} & =-2^{*} 10^{-6 *} \mathrm{RPM}^{2}+0.0355^{*} \mathrm{RPM}+77.5 \\
& =-2^{*} 10^{-6 *} 6000^{2}+0.0355^{*} 6000+77.5 \\
& =218.5 \mathrm{~K} \\
\mathrm{Q}_{\text {Eng }} & =0.77^{*} 0.570^{*}(218.5-30) \\
& =82.73 \mathrm{~W}
\end{aligned}
$$

\section{Ventilation Load}

According to psychrometric calculations, ventilation heat gain consists of both sensible and latent loads. To account for both these terms, assuming a known flow rate of fresh air entering the cabin, the amount of thermal heat gain can be calculated from

$\mathrm{Q}_{\mathrm{Ven}}=\mathrm{m}_{\mathrm{Ven}}\left(\mathrm{e}_{0}-\mathrm{e}_{\mathrm{i}}\right)$

Where $m_{\text {ven }}$ is the ventilation mass flow rate and eo and ei are the ambient and cabin enthalpies, respectively. Enthalpies are calculated from

$$
\begin{array}{ll}
\mathrm{e} & =1006^{*} \mathrm{~T}+\left(2.501^{*} 10^{6}+1770 \mathrm{~T}\right) \mathrm{X} \\
\mathrm{e}_{0} & =1006^{*} 40+\left(2.501^{*} 10^{6}+1770^{*} 40\right) 0.3\left(\mathrm{~T}_{0}=40, \mathrm{X}=0.3\right) \\
& =811780 \mathrm{~J} / \mathrm{kg} \\
\mathrm{e}_{\mathrm{i}} & =1307230 \mathrm{~J} / \mathrm{kg}\left(\mathrm{T}_{\mathrm{i}}=30, \mathrm{X}=0.5\right)
\end{array}
$$

Where $\mathrm{T}$ is air temperature and $\mathrm{X}$ is humidity ratio in gram of water per gram of dry air.

$$
\begin{aligned}
m_{\text {Ven }} & =0.02 \mathrm{~kg} / \mathrm{s} \\
Q_{\text {Ven }} & =0.02(811780-1307230) \\
& =-9909 \mathrm{~W}
\end{aligned}
$$

\section{$7 \quad$ AC Load}

The duty of the air conditioning system is to compensate for other thermal loads so that the cabin temperature remains within the acceptable comfort range. In cold weather conditions, positive AC load (heating) is required for the cabin. Inversely, in warm conditions, negative AC load (cooling) is needed for maintaining the comfort conditions. The actual load created by the AC system depends on the system parameters and working conditions. In this work, it is assumed that an AC (or heat pump) cycle is providing the thermal load calculated by ${ }^{[4]}$

$Q_{A C}=-\left(Q_{M e t}+Q_{D i r}+Q_{D i f}+Q_{R e f}+Q_{A m b}+Q_{S . R a d}+Q_{E x h}+Q_{E n g}+Q_{V e n}\right)-$ $\left(\mathrm{m}_{\mathrm{a}} \mathrm{c}_{\mathrm{a}}+\mathrm{DTM}\right)\left(\mathrm{T}_{\mathrm{i}}-\mathrm{T}_{\text {Comf }}\right) / \mathrm{t}_{\mathrm{c}}$

Here $\mathrm{m}_{\mathrm{a}}=44.488 \mathrm{~kg}$

$\mathrm{C}_{\mathrm{a}}=1.005$

$\mathrm{DTM}=5.6 \mathrm{~kJ} / \mathrm{kg}$

$\mathrm{T}_{\text {Comf }}=20$

$\mathrm{T}_{\mathrm{i}}=30$

$\mathrm{t}_{\mathrm{c}}=600 \mathrm{sec}$

$\mathrm{Q}_{\mathrm{AC}}=-(6.76)-0.8348 \mathrm{KW}$

$=5.93 \mathrm{~kW}$

$1 \mathrm{TR}=3.5 \mathrm{~kW}$

$\mathrm{Q}_{\mathrm{AC}}=5.93 / 3.5$

$=1.69 \mathrm{TR}$

From ASHRAE standard 2007 1TR is equal to $400 \mathrm{CFM}$

\section{Power Calculation}

To supply 676 CFM blower should run at $890.66 \mathrm{rpm}$ therefore we considered as $900 \mathrm{rpm}$

\section{Blower Capacity}

we are assumed that blower of company named "American fan". As per standards power required to run the blower at $900 \mathrm{rpm}$ is $3 / 4 \mathrm{HP}$. So power required to run the blower is 559 Watts $=0.559 \mathrm{KW}$

\section{Compressor Capacity}

Type of Compressor $=$ Swash Plate Type

Piston $=5$ Pistons

Displacement $=117 \mathrm{cc}$

Compressor oil= Denso 8

Type of pulley $=$ Polygroove

Pressure Range $=1.3 \mathrm{MPa}$ (inlet) to $2.7 \mathrm{MPa}$ (outlet) 
Rated power $(25 \mathrm{~V})=738 \mathrm{~W}(2 \mathrm{TR})$

Therefore power required for $1.69 \mathrm{TR}$ is $738 \mathrm{~W}=0.738 \mathrm{KW}$

So total power required both blower and compressor is $1.297 \mathrm{KW}$.

\section{Solar Panel}

Roof area of car (top) $=0.94 \mathrm{~m}^{2}$

Due to lack of possibility of ideal angle formation between sun rays and solar panels, panels may work with less effectiveness, so a lower photovoltaic efficiency of $13 \%$ is taken for this system design calculations.

Average sunshine received in India $=5.4 \mathrm{kWh} / \mathrm{m}^{2}$

Power generated when panel receive whole day sunshine: = $5.4 \mathrm{kWh} / \mathrm{m}^{2} \times 0.94 \mathrm{~m}^{2} \times 0.13$

$=0.6598 \mathrm{kWh}$

So power generated by solar panel of $0.94 \mathrm{~m}^{2}$ is $0.6598 \mathrm{KWh}$ Therefore power required to drive the compressor and blower is we need the surface area of nearly $1.2 \mathrm{~m}^{2}$. Therefore power generated by solar panel is not sufficient to run the compressor and blower. So design of solar air conditioning for four wheeler does not hold good.

In order to gain such a high power of small surface area of solar panel is solar calls are made up of plasmonic solar cells. In thin-film solar cells, it becomes important to trap the solar energy that is incident on it. Hence, Plasmonic nanoparticles will prove to be effective to increase the efficiency of the solar cells

The structure of the proposed solar cell consist of four ordered layer : an 80-nm SnO2:F transparent conductive oxide layer on the front, followed by a 350-nm hydrogenated amorphous silicon (a-Si:H) active layer, afterwards a layer of Al-doped $\mathrm{ZnO}$ (ZnO:Al) thin film into which the $\mathrm{Ag}$ nanoparticles are regularly deposited, and finally a $120-\mathrm{nm}$ $\mathrm{Ag}$ back reflector. by this type there is chance to gain required power[5].

\section{RESULT}

The heat load obatained are follows
\begin{tabular}{|c|c|}
\hline Type of load & Q(W) \\
\hline Metabolic load & 533.5988112 \\
\hline Radiation load & 1565.12 \\
\hline Ambient load & 87.315 \\
\hline Exhaust load & 15.88 \\
\hline Engine load & 82.73 \\
\hline Ventilation load & -9909 \\
\hline Ac load & 5935.14 \\
\hline
\end{tabular}

The TR obatained by calculating above load is 1.69 TR

\begin{tabular}{|c|c|}
\hline Type & Power KW \\
\hline Blower & 0.559 \\
\hline Compressor & 0.738 \\
\hline Total power & 1.297 \\
\hline
\end{tabular}

Average sunshine received in India $=5.4 \mathrm{kWh} / \mathrm{m}^{2}$

Power generated when panel receive whole day sunshine: = $5.4 \mathrm{kWh} / \mathrm{m}^{2} \times 0.94 \mathrm{~m}^{2} \times 0.13$

$=0.6598 \mathrm{kWh}$

So power generated by solar panel of $0.94 \mathrm{~m}^{2}$ is $0.6598 \mathrm{KWh}$

\section{CONCLUSION}

The top surface area of car is $0.94 \mathrm{~m}^{2}$. By this average solar energy produced $0.6598 \mathrm{KWh}$. But energy needed to run the compressor and blower is 1.297 KW. Therefore energy produced is not sufficient to supply 660 CFM of capacity 1.67 TR.

Therefore we cannot increase the dimensions of solar panel as it may damage the near by vehicle on roads or it may be difficult in parking.

So the result designing of solar air conditioning for four wheeler does not hold good. Therefore $1.69 \mathrm{TR}=676 \mathrm{CFM}$.

\section{REFERENCES}

[1] Ravi Gugulothu, Naga Sarada Somanchi, Hima Bindu Banoth \& Kishan Banothu," A Review on Solar Powered Air Conditioning System", Science Direct, Procedia Earth and Planetary Science 11 (2015) 361-367.

[2] Khaled S. Al Qdah, "Performance of Solar Power Air Conditioning System Under Almadinah AlMunawwarah Climatic Conditions",Smart Grid and Renewable Energy,2015,6,209-219.

[3] Edlas Khor Jiunn Hao and Ali GhaffarianHoseini," Solar vs. Conventional Air- Conditioning Systems: Review of LIMKOKWING University Campus, Cyberjaya,Malaysia", Journal of Creative Sustainable Architecture \& Built Environment, Vol.2, December,2012

[4] Ingersoll, J., Kalman, T., Maxwell, L., and Niemiec, R., "Automobile Passenger Compartment Thermal Comfort Model - Part I: Compartment Cool-Down/Warm-Up Calculation," SAE Technical Paper 920265, 1992, doi: $10.4271 / 920265$.

[5] S S Verma, 'Plasmonic Solar Cells' 